\title{
ВИЩА ОСВIТА
}

УДК 004:378.046. 2

DOI: http://doi.org/10.31617/visnik.knute.2020(130)01

\author{
МАЗАРАКІ Анатолій, \\ д. е. н., професор, ректор \\ Київського національного торговельно-економічного університету \\ вул. Кіото, 19, м. Київ, 02156, Україна \\ E-mail: mazarakiaa@knute.edu.ua \\ ORCID: https://orcid.org/0000-0001-5283-8444
}

НОВІКОВА Наталя,

д. е. н., доцент, завідувач кафедри

публічного управління та адміністрування

Київського національного

торговельно-економічного університету

вул. Кіото, 19, м. Київ, 02156, Україна

E-mail: n.l.novikova@knute.edu.ua

ORCID: https://orcid.org/0000-0001-5219-9494
СОНЬКО Юлія,

к. е. н., доцент, доцент кафедри публічного управління та адміністрування

Київського національного торговельно-економічного університету вул. Кіото, 19, м. Київ, 02156, Україна

E-mail:y.sonko@knute.edu.ua ORCID: http://orcid.org/0000-0002-2557-9069

\section{ЩФРОВI ДЕТЕРМІНАНТИ ТРЕНДІВ ПІДГОТОВКИ ФАХІВЦІВ}

Розглянуто основні тендениії цүифровізаиії суспільства та перспективи його подальшого розвитку. Обтрунтовано необхідність формування цифррових компетентностей (Digital skills) майбутніх фахівців різних сфер економіки України, органів влади та громадськості у контексті розвитку глобального тренду иифрової трансформації суспільства. Розроблено методологічні алгоритми побудови курсу "Цифрова економіка України" відповідно до сучасних трендів підвищення якості освіти.

Ключові слова: цифрова економіка, цифрові компетентності, цифрові тренди, освітній процес, якість освіти, цифровізація.

Мазараки А., Новикова Н., Сонько Ю. Цирровье детерминанты трендов подготовки специалистов. Рассмотрены основные тенденции цуифровизации общества u перспективы его дальнейтего развития. Обоснована необходимость формирования цифровых компетентностей (Digital skills) будущих специалистов различных сфер экономики Украины, органов власти и общественности в контексте развития глобального тренда ичифровой трансформации общества. Разработаны методологические алгоритмы построения курса "Цифровая экономика Украины" в соответствии с современными трендами повышения качества образования.

Ключевые слова: цифровая экономика, цифровые компетентности, цифровые тренды, образовательный процесс, качество образования, цифровизация.

Постановка проблеми. Нова епоха цифровізації, в яку стрімко увійшов світ, результати четвертої промислової революції ("Індустрія 4.0") вносять радикальні корективи в традиційний уклад життя, кардинально

(C) Мазаракі А., Новікова Н., Сонько Ю., 2020

ISSN 1727-9313. ВIСНИК КНТЕУ. 2020. 
трансформуючи суспільство. Переміщення аналогових операцій в інтернет-простір, розвиток цифрового середовища, заміна класичних моделей управління та бізнес-процесів цифровими продукують якісно новий формат промислового виробництва, розкриваючи нові можливості персоналізації пропозицій для кожного клієнта. Процеси цифровізації та роботизації, зумовлюючи появу унікальних систем і процесів, є імперативом сучасного глобалізованого світу. Цифрові технології змінюють практично всі сфери життя, складають їх нову ціннісну сутність, сприяють зростанню ефективності й продуктивності праці, паралельно зменшуючи попит на людський ресурс.

Відповідно до звіту про охоплення цифровізації (Digita LSpillover) до 2022 р. буде оцифровано понад 60 \% світового ВВП. Орієнтовні 70 \% нової вартості, створеної в економіці протягом наступного десятиліття, базуватимуться на платформах 3 цифровою підтримкою. Глобальний центр інфраструктури оцінює глобальний дефіцит фінансування майже в 1 трлн дол. США на інфраструктуру інформаційних та комунікаційних технологій до 2040 р. [1].

Прискорюючи процеси передання знань, інтеграції інновацій у бізнес, формуючи конкурентні переваги розвитку економічних систем різних рівнів, глобальна цифрова економіка стрімко зростає й розвивається. За прогнозами Бостонської консалтингової групи (The Boston Consulting Group), вона зростала в 2.5 раза швидше, ніж глобальний ВВП за останні 15 років і майже вдвічі з 2000 р. Обсяг світової цифрової економіки може досягнути рівня 16 трлн дол. США до 2035 р. [2].

Експерти Всесвітнього економічного форуму в Давосі у своєму звіті "Готовність до майбутнього виробництва" (Digital Transformation Initiative) зазначають, що для України зосередитися на цифровізації правильний і єдиний спосіб скоротити настільки відчутний розрив у міжнародних показниках порівняно з іншими країнами світу [3].

Означене актуалізує необхідність впровадження в освітній процес курсу "Цифрова економіка України". Його вивчення має на меті надання здобувачам вищої освіти різних спеціальностей грунтовних теоретичних знань і набуття практичних навичок застосування цифрових технологій у різних секторах економіки, бізнесу, публічного управління для підвищення їх ефективності, конкурентоспроможності, забезпечення сталого національного розвитку, зростання обсягів виробництва високотехнологічної продукції та добробуту населення України. В процесі навчання здобувачі вищої освіти зможуть усвідомити сутність цифровізації суспільства, ознайомитися з сучасними цифровими трендами, вивчити особливості концепцій та сценаріїв цифровізації у різних країнах світу.

Аналіз останніх досліджень і публікацій. Напрями цифровізації суспільства досліджували такі провідні науковці, як: О. Аполов [4], Р. Бухт [5], О. Джусов [6], О. Гудзь [7], Г. Карчева [8], С. Коляденко [9], Т. Писаренко [10], О. Піжук [11] та ін. Питання розвитку цифрової еконо- 
міки у центрі уваги науковців Державної установи "Інститут економіки та прогнозування НАН України" (В. Ліпов [12], І. Одотюк [13]), а також науковців Інституту економіки промисловості НАН України (В. Ляшенко та О. Вишневський [14]).

Однак поза увагою залишаються питання безперервної адаптації сучасних компетентностей майбутніх фахівців відповідно до цифрової трансформації суспільства.

Метою дослідження є обгрунтування необхідності формування цифрових компетентностей (Digital skills) майбутніх фахівців різних сфер економіки України, органів влади та громадськості у контексті розвитку глобального тренду цифрової трансформації суспільства та розробка методологічних алгоритмів побудови курсу "Цифрова економіка України" для здобувачів вищої освіти України.

Матеріали та методи. Матеріалами досліджень слугували кількісні показники розвитку процесу цифровізації суспільства, дані міжнародних рейтингів України в частині складових, пов'язаних з цифровізацією, публікації науковців, які вивчали питання цифрових трансформацій в Україні та світі, офіційні звіти міжнародних організацій, нормативно-правові акти та ін. Використано широкий спектр загальнонаукових та спеціальних методів економічних досліджень, зокрема аналізу та синтезу, наукового абстрагування, узагальнення, статистичного аналізу, порівняння, систематизації.

Результати дослідження. Цифровізація економіки України - це ключовий драйвер підвищення конкурентоспроможності іiі секторів та галузей, добробуту громадян, розвитку ринку праці, появи нових індустрій, створення нових продуктів, властивостей та цінностей. Це єдино правильний шлях до економічного зростання України, формування конкурентних переваг та розвитку інноваційного підприємництва у глобальному цифровому середовищі.

Особливого значення при цьому набуває система вищої освіти. Для адаптації до цифрового середовища, крім "гнучких" (Soft skills), "професійних" (Hard skills) навичок, необхідні ще різні типи цифрових знань, які формують цифрові компетентності. Забезпечення освітнього процесу відповідним навчально-методичним інструментарієм сприяє формуванню у здобувачів сучасних цифрових компетентностей (Digital skills) (далі - DS). За експертними оцінками, до 2030 р. від 75 до 375 млн працівників, які становлять від 3 до 14 \% світової робочої сили, будуть змушені змінити свою професію [15]. Стає актуальним міркувати не стільки з точки зору кількості робочих місць, скільки з точки зору формування необхідних компетентностей та навичок і пристосовування їх до потреб ринку праці. Формування $D S \epsilon$ однією з найважливіших умов для розвитку цифрового ринку будь-якої країни, оскільки воно прямо або опосередковано пов'язане з усіма сферами функціонування суспільства. Цифрові компетентності вважаються вихідною 
рамковою умовою для розвитку всіх інших пріоритетів у сфері гармонізації цифрових ринків країн СС та Східного Партнерства, визначених під час засідання на тему "Цифрова спільнота" (2016 р., Брюссель) на рівні міністрів [16].

Європейською спільнотою здійснено значну роботу щодо рамок цифрової компетентності для: громадян (DigComp), педагогів (DigCompEdu), освітніх організацій (DigCompOrg) та споживачів (DigCompConsumers). У 2016 р. опубліковано систему підходів до відкритих закладів вищої освіти $(O p e n E d u)$, а також рамка підприємницької компетентності (EntreComp), в галузі обчислювального мислення (CompuThink) [17].

У динамічному цифровому світі технології розвиваються з безпрецедентною швидкістю, тому освітні програми потребують постійного оновлення для задоволення потреб ринку праці. Якість вищої освіти насамперед визначається відповідністю змісту навчання до потреб майбутньої професії, тому наразі питання ії підвищення стає як ніколи актуальним.

Відповідно до нових викликів мають змінюватись й тренди підготовки фахівців. Отже, врахування цифрових детермінант у трендах підготовки фахівців є пріоритетним завданням для КНТЕУ. Для його реалізації розроблено курс "Цифрова економіка України", метою вивчення якого $є$ надання фундаментальних теоретичних знань і набуття практичних навичок та умінь вирішення професійних завдань, що виникають у різних сферах цифрової економіки.

Завдання вивчення курсу "Цифрова економіка України" - надання здобувачам вищої освіти різних спеціальностей грунтовних знань, необхідних для управління економічними об'єктами в процесі їх цифровізації, впровадження цифрових технологій у секторах промисловості, бізнесі та державному управлінні для підвищення їх ефективності, конкурентоспроможності, забезпечення сталого національного розвитку, зростання обсягів виробництва високотехнологічної продукції та благополуччя населення України. Предметом вивчення курсу є основні положення та стратегії політики цифровізації соціально-економічного розвитку України.

Стосовно змісту курсу, то цифрові тренди як напрями розвитку цифрових технологій пропонується розглядати в темі "Концептуальні засади цифрової трансформації суспільства". Адже для більшості сфер та галузей економіки України використання цифрових трендів $\epsilon$ вкрай актуальним. Вони фактично є готовими стратегіями відповідних рішень, ініціатив та дій. Використання цифрових трендів, вивчення національних, регіональних, місцевих ініціатив з цифрової трансформації України, аналіз сценаріїв цифрового розвитку може бути критичним для подолання великої кількості економічних та соціальних викликів країни. Цифрові тренди здатні трансформувати систему, сферу, галузь у нову якість, зробити це швидше та дешевше, ніж традиційні аналогові підходи. Кінцевим результатом є ефективність, конкурентоспроможність та створення нових цінностей. 
Поява в структурі економіки України значної частки цифрової економіки (до 65 \% ВВП), національна ініціатива цифровізації українського суспільства на принципах цифрового пріоритету та на засадах державно-приватного партнерства, фокус на розвитку внутрішнього ринку, формування у ключових стейкхолдерів (держава, бізнес, громадяни) мотивацій, потреб та попиту у цифрових технологіях здатне стрімко підвищувати продуктивність економіки.

Аналізуючи останні дослідження і публікації, можна виокремити п’ять основних умов успішної цифровізації в Україні: доступність та сприйняття, забезпечення конкурентних переваг, загальна відповідальність, відповідність та цілеспрямованість, безпечність та захищеність, що ілюструє рис. 1 .

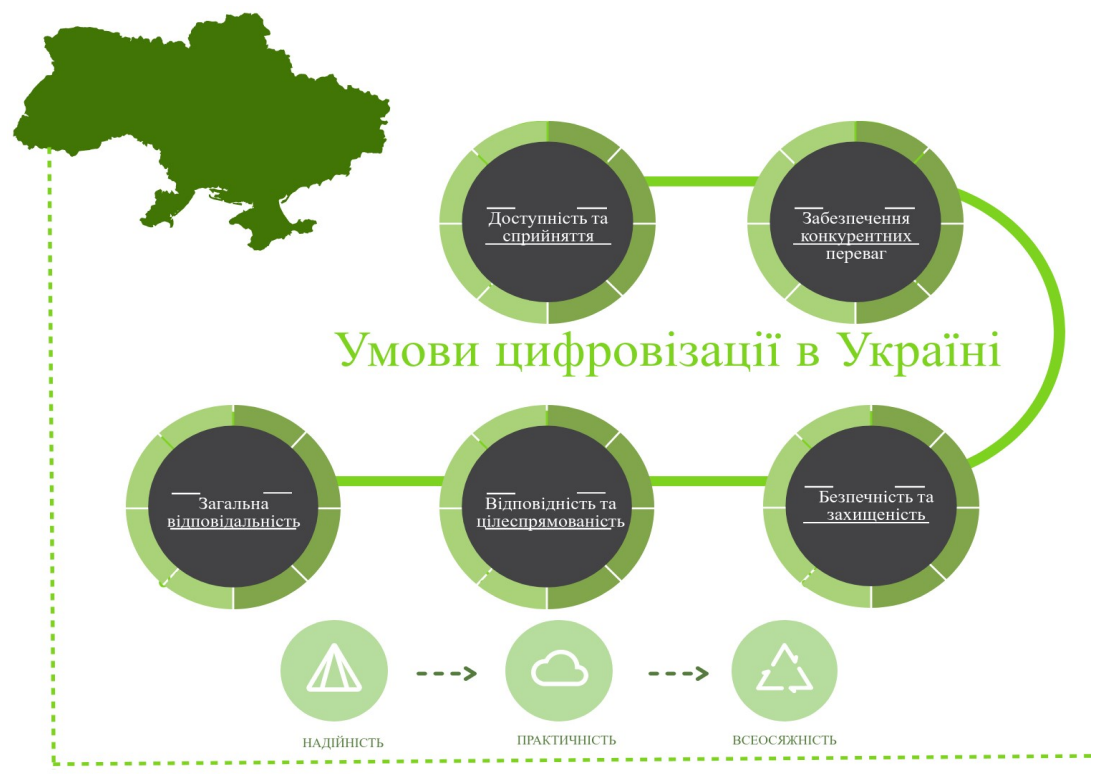

Рис. 1. Умови цифровізації в Україні

Джерело: авторська розробка.

Доступність та сприйняття: кожен громадянин, незалежно від місця проживання, статі, доходу, має доступ до мережі Інтернет та вміє нею користуватися. Достатній рівень цифрової грамотності населення.

Забезпечення конкурентних переваг: підвищення конкурентоспроможності бізнесу в умовах глобальної конкуренції. Технічне переоснащення вітчизняних підприємств усіх форм власності, ефективне залучення досягнень цифровізації у процесі діяльності.

Загальна відповідальність: підприємства, держава, громадські організації взаємодіють злагоджено в процесі реалізації концепції цифровізації. Ефективне публічно-приватне партнерство, в основі якого застосування досягнень цифрової економіки. Суттєвий рівень довіри до бізнесу та до влади. Соціальна спрямованість не лише державної політики, а й бізнесової діяльності.

ISSN 1727-9313. ВІСНИК КНТЕУ. 2020. № 2 
Відповідність та иілеспрямованість: слідування основним принципам, визначеним на рівні держави. Чіткий, сформований курс реформ щодо формування цілісного механізму цифровізації економіки. Неперервність та невідворотність запущених механізмів цифровізації в Україні. Впровадження новітніх технологій на всіх рівнях від "цифрового робочого місця" до реалізації концепції "розумні міста".

Безпечність та захищеність: розвинена система захисту баз даних. Створення безпечного кіберпростору. Нівелювання впливу інформаційної асиметрії. Своєчасне висвітлення офіційної інформації. Держава має взяти на себе роль лідера й експериментатора; регулятора й захисника; популяризатора цифрових трансформацій в Україні.

Основними принципами впровадження цих умов $\epsilon$ надійність, практичність та всеосяжність. Надійність передбачає стійкість у прийнятті рішень щодо проведення реформ у межах впровадження цифровізації, неухильне слідування визначеним цілям. Практичність визначає використання досягнень цифровізації 3 метою отримання переваг. Тобто зміни мають з самого початку бути ефективними і рентабельними. Щодо всеосяжності, то цей принцип має на меті одночасне впровадження технологій на всій території держави, а не тільки в столиці чи великих містах.

Впровадження цифровізації надасть можливість Україні посісти гідне місце серед європейських країн у галузі інновацій. Для цього необхідним є більше 60 \% цифрового ВВП, 100 \% охоплення мережі Інтернет, у тому числі покриття $4 G-5 G$, доступність мобільного Інтернету на транспортному сполученні, активне використання цифрової ідентифікації громадян тощо.

Оскільки цифрова економіка за своїми характеристиками є глобальною, цифрові тренди також мають глобальний характер та вплив. Тому актуальною $є$ тема курсу "Загальносвітові тенденції цифровізації", де, крім типів цифрових економік та особливостей концепцій та сценаріїв цифровізації у різних країнах світу, пропонується розглянути ініціативи СС щодо розвитку цифрової економіки: "Індустріальна політика для ери глобалізації" (Industrial Policy for Globalisation Era); "Цифровий порядок денний Свропи" (Europe Digital Agenda); Стратегія "Підприємницька діяльність - 2020" (The Entrepreneurship, 2020). Важливим завданням є гармонізація України в цифровий єдиний ринок (Digital Single Market) - платформа СС щодо розвитку транскордонної економічної взаємодії та комерції.

У світі не існує єдиного концептуального підходу до оцінки обсягів цифрової економіки, впливу цифровізації на зростання ВВП. Ці важливі питання ми пропонуємо розглянути в темі "Оцінка макроефектів від цифровізації для ключових стейкхолдерів", де наведено ефекти від цифровізації для бюджету держави: інвестиції у цифровізацію виробництва, бізнесу, промисловості; додаткові надходження 
до бюджету; інвестиції у цифрову інфраструктуру; приріст продуктивності праці; додатково створений ВВП завдяки цифровізації; кількість створених робочих місць. Ефекти від цифровізації для бізнесу: зростання промислового виробництва, високотехнологічних сегментів, пропускної здатності виробництв, кількості замовлень, виконаних вчасно, ефективності встановленого обладнання; скорочення запасів, простоїв обладнання; економія витрат на закупівлю; додаткове залучення до країни інвестицій у розвиток "Індустрії 4.0" - як у виробництва, так і в центри $R \& D$, інкубатори та технологічні компанії.

Ефекти від цифровізації для громадян: можливість капіталізації себе, своїх знань, вмінь та навичок завдяки використанню цифрових технологій; використання онлайн-сервісів та платформ для розвитку своїх бізнесів через власні боти та цифрові особисті "копії", без посередників і роботодавців; зростання доходів, тривалості та якості життя (доступ до якісної медицини, освіти; гарантована безпека кожної людини; взаємодія громадян з державою через електронний кабінет - економія часу, грошей, комфорт). Це лише деякі варіанти розвитку подій. Враховуючи експоненціальний характер змін завдяки цифровим детермінантам, реальна картина може бути непередбачуваною.

Головним макроефектом цифровізації є зміна ланцюжків створення доданої вартості. Вплив цифровізації визначається доданою вартістю, яку вона створює для кожної сфери економіки, кардинально змінюючи їі структуру. За результатами досліджень Digital Spillover у майбутньому більше 70 \% зайнятості буде реалізовано у видах діяльності, які сьогодні ще не існують. Одночасно відбувається стрімке зростання окупності інвестицій. Кожен долар США, інвестований у цифрові технології, зумовлює зростання ВВП на 20 дол. США [1].

Таким чином, розвиток цифрової економіки в Україні на першому етапі супроводжуватиметься негативними процесами, тенденціями втрати роботи громадянами, проте саме цифровізація і стане платформою для появи нових робочих місць та суттєвої трансформації наявних.

Цифрові трансформації у промисловості відбуваються згідно 3 концепцією "Індустрія 4.0", тенденції яких ми також пропонуємо розглянути в ході вивчення курсу. За даними дослідження "Цикл зрілості IT-трансформації" (ESG IT Transformation Maturity Curve), проведеного компанією Enterprise Strategy Group (ESG), 96 \% компаній, які пройшли цифрову трансформацію, майже вдвічі перевиконали свої плани по доходах у минулому році; $71 \%$ компаній згодні, що втрачають конкурентоспроможність без цифрової трансформації; 95 \% респондентів визнали, що програють конкурентам, які вже пройшли етап цифрової трансформації. Серед успішно трансформованих компаній 85 \% вважають, що їх організації в найближчі кілька років зможуть успішно конкурувати і процвітати на своїх ринках, обійшовши компанії, які знаходяться на більш ранніх стадіях цифрової трансформації [18]. Ефекти від розвитку "Індустрії 4.0", консолідація головних ії стейк- 
холдерів та урядових структур навколо цілей та програм розвитку "Індустрії 4.0", залучення IT-сектора до проблем розвитку внутрішнього ринку - розгляд цих актуальних питань включено до змісту курсу "Цифрова економіка України", як і аналіз кращих практик економії бюджетних коштів на утримання апарату влади завдяки цифровізації. Так, у Нідерландах лише 400 співробітників об'єднаних центрів обслуговування обслуговують 150000 державних службовців, які працюють у різних органах влади. Сумарна економія від такої структурної оптимізації становить близько 250 млн євро. Таким чином, цифровізація бізнесу, промисловості, публічного сектора стає головним чинником модернізації економіки.

У темах курсу особливу увагу приділено иифровій трансформації аграрної сфрери Украӥни як новому етапу ії розвитку. Здорове суспільство, збільшення тривалості життя, зниження рівня захворюваності населення - все це результати ефективної реалізації стратегії цифрового (точного) землеробства, яка базується на застосуванні цифрових технологій, використанні геоінформаційних систем, бортових комп'ютерів, інших цифрових механізмів, здатних якісно контролювати норми внесення добрив, способи обробітку та засоби захисту рослин з урахуванням просторової неоднорідності поля. Впровадження точних цифрових технологій в аграрній сфері сприятиме підвищенню ефективності використання земельного банку країни, зростанню врожайності та ефективності охорони довкілля. Заслуговує уваги й соціальний ефект цифровізації аграрної сфери - використання цифрових технологій сприятиме збільшенню доходів сільського населення, рівня їх економічної культури й екологічної свідомості. Підвищення привабливості праці на селі дасть змогу знизити рівень безробіття та міграції сільської молоді. Цифровізація аграрного сектора, в свою чергу, сприятиме цифровізації села, максимальному наближенню якості життя на селі до рівня міст та відродженню сільських територій.

Окремою темою курсу є питання цифрової трансформації у сфері охорони здоров'я Украӥни. Затвердження національних стандартів цифрової медицини України, перехід медичного документообігу у цифровий формат - оцифровування даних медичних карт, запровадження архівно-резервних функцій (Computerized Medical Record), оцифровування архівних медичних карт (Electronic Medical Record), уніфікація Electronic Medical Record iз різних медичних закладів та об'єднання в одній базі (Electronic Patient Record), ідентифікація користувачів системи eHealth (Electronic Identifiers), виписка (smart open service for European patients), система допомоги у прийнятті рішень для клініцистів (CDSS clinical decision support system), електронний рецепт (ePrescription), формування електронного рецепту лікарем медичного закладу (eCapture); конфіденційне передання електронного рецепту до аптеки (eTransfer), передання даних з аптеки назад до медичного зак- 
ладу, підтвердження (eDispensation), цифрові технології для надання дистанційних медичних послуг та підтримки роботи лікарів (TeleHealth), пакет електронних документів, що надаються органам соціального страхування або медичним закладам для отримання компенсації (eMedical Claim Forms) - весь цей динамічний набір систематизованих даних про стан здоров'я пацієнта забезпечується використанням цифрових технологій у формуванні інформаційного обміну між учасниками процесів відтворення у сфері охорони здоров'я. Також здобувачам вищої освіти пропонується ознайомитись із національними та європейськими програмами та стратегіями в сфері охорони здоров'я - програма Європейського Союзу "Свропейська стратегія здоров'я 2030"; національна стратегія "Здоров'я нації 2030"; цифрові платформи електронної охорони здоров'я eHealth, Digital Health, національна система Electronic Health Record (EHR).

3 огляду на специфіку КНТЕУ, здобувачам вищої освіти цікаво буде ознайомитись з тенденціями циффрової трансформації торгівлі. Пропонуються на розгляд актуальні питання розвитку е-торгівлі (e-commers): зростання кількості мобільних трансакцій, розвиток омніканалів, перехід BtoB продаж в онлайн, розвиток сервісів доповненої реальності, розширення використання голосу і зображень для взаємодії онлайн. Здобувачам вищої освіти корисно буде проаналізувати бар'єри у сфері розвитку е-торгівлі: недостатня безпека даних (кіберзлочини та шахрайство) та недостатній розвиток інтернет-комунікацій (максимальне покриття, пропускна спроможність каналів та швидкість передання даних).

До розгляду пропонуються питання визначення залежності між розвитком "цифрової" інфраструктури країни та розвитком ринку електронної комерції. Вивчення мобільного сегмента e-commers, верифікації платежів та цифрові технології в e-commers: розширення способів здійснення оплати; використання "електронних" грошей; онлайн-кредитування; "смарт-логістика" та супутні послуги; покращання "цифрових" навичок громадян; розвиток транскордонної електронної торгівлі; програми СC Digital Single Market; фулфілмент-послуги міжнародних торгових площадок.

Цифрові технології мають величезний потенціал реалізації у сфері екології та природних ресурсів Украӥни. Ці актуальні питання широко висвітлені в курсі "Цифрова економіка України". Складові опрацювання теми "Цифровізація сфери екології та природних ресурсів України" охоплюють вивчення інтегрованої електронної системи екологічної інформації; спільної системи екологічної інформації ЄС (Shared Environmental Information System, SEIS) та інтеграції до неї України; системи екологічного моніторингу; електронного інтегрованого дозволу у сфері екології та природних ресурсів; Smartusage (розумне та відповідальне користування та забезпечення доступності ресурсів, санітарії та гігієни); Smartenergy (розумне споживання енергії, підвищення ефективності виробництва та постачання енергіï); Smartcitymanagement (розумне ефекISSN 1727-9313. ВІСНИК КНтЕУ. 2020. № $2=13$ 
тивне й цілісне планування та управління містами); Cleanair (забезпечення чистоти повітря, атмосфери); Smartecosystems (розумне використання наземних та водних екосистем і запобігання втраті біорізноманіття).

Одночасно важливо звернути увагу здобувачів вищої освіти на негативні наслідки цифровізації сфери екології. Йдеться про те, що збільшення споживання енергії, у свою чергу, призводить до посилення впливу на навколишнє середовище. Тому важливо акцентувати увагу здобувачів вищої освіти на вивченні питань реалізації публічної політики в сфері екології та природних ресурсів України, створення національної системи незалежного екологічного моніторингу та оцінки водних екосистем та водопостачання, стимулювання створення бізнесом та громадськістю мобільних додатків "екологічного патрулювання" з метою мінімізації негативних наслідків стану атмосферного повітря, екосистем суші.

Для формування фахових компетентностей здобувачів вищої освіти [19] галузей знань 051 - Економіка, 28 - Публічне управління та адміністрування, 07 - Управління та адміністрування особливий інтерес становлять теми курсу, які досліджують питання цифрової трансформації у сферах фінансової та бюджетної політики, публічної безпеки, електронної демократії та електронної держави, електронних послуг, створення цифрової інфраструктури, цифровізації сфери ідентифікації громадян. Попри багатогранну специфіку кожної з них, яка грунтовно аналізується при вивченні курсу, хотілося б звернути увагу на роль держави - такого собі "цифрового революціонера-фарватера", лідера процесів тотальної цифровізації України за принципом "цифра всюди, постійно, наскрізь". Держава розглядається як інтелектуальний хаб для розвитку людського потенціалу, який використовує для реалізації публічної політики "смарт-активізму" сучасний інструментарій регулювання - формування мотивацій у споживачів технологій (ініціативи щодо забезпечення фінансової доступності "цифрових" технологій для споживачів, доступності фінансових ресурсів для закупівлі або кредитування проектів цифровізації бізнесу, промисловості); формування потреб у споживачів (ініціація національних проектів цифровізації та пошук релевантних моделей державно-приватного партнерства для їх реалізаціі). Економічний інтерес від цифровізації мають усі стейкхолдери - держава, бізнес, громадяни. Для всіх без винятку це нові можливості для реалізації, розвитку інноваційних та креативних індустрій.

Не менш важливою та цікавою для здобувачів вищої освіти є тема, присвячена оичниі розвитку процесів изифровізації. Серед усієї множини індексів, що дають змогу оцінити рівень розвитку цифровізації для тієї чи іншої країни, найбільшої уваги заслуговують такі: індекс мережевої готовності, глобальний індекс інновацій, індекс розвитку інформаційнокомунікаційних технологій (IКТ), глобальний індекс конкурентоспроможності. На рис. 2 проілюстровано місце України в міжнародних рейтингах оцінки розвитку процесів цифровізації. 


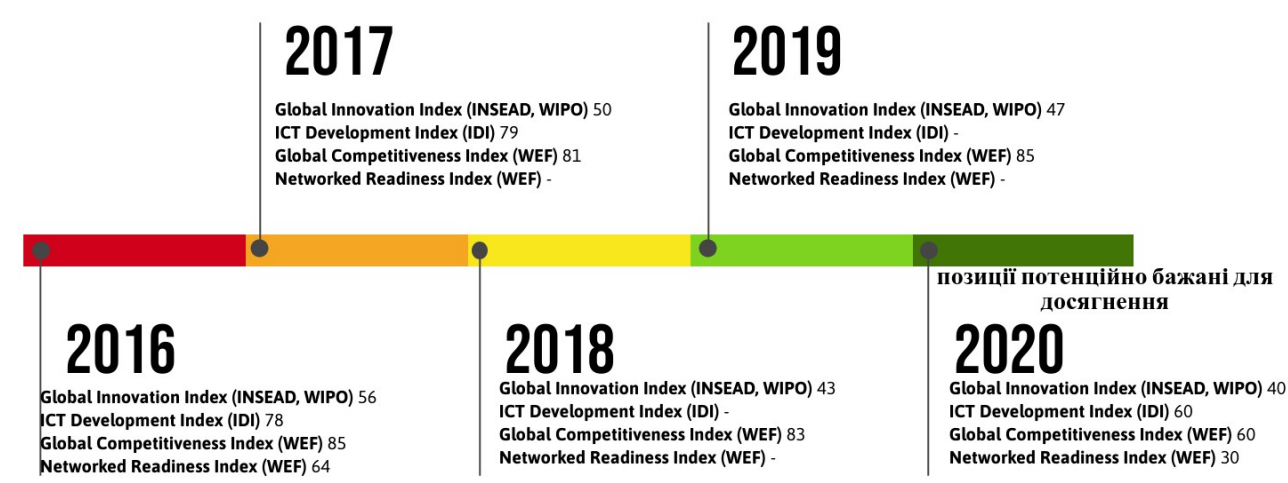

Рис. 2. Україна у світових рейтингах оцінки розвитку процесів цифровізації Джерело: складено авторами за [20-24].

Networked Readiness Index (NRI) [24] - індекс мережевої готовності Всесвітнього економічного форуму $(W E F)$, який публікується у рамках щорічного звіту про глобальні інформаційні технології. Індекс передбачає оцінку наявності умов для розвитку ІКТ, врахування того, наскільки активно ІКТ використовують уряд, бізнес та суспільство, а також визначення значимості ІКТ для економічного зростання. Востаннє зазначений індекс розраховувався 2016 р., тоді Україна посіла 64 рейтингову позицію серед 139 країн світу, покращивши результати на 7 пунктів, порівняно з попереднім періодом. У "Концепції розвитку цифрової економіки України" вказане 30 місце в рейтингу Networked Readiness Index (NRI) як потенційно бажане для досягнення у 2020 p.

Global Innovation Index (GII) [22] - глобальний індекс інновацій, що розраховується Свропейським інститутом ділового адміністрування (INSEAD), одним з найбільш прогресивних європейських бізнес-шкіл з кампусами в Свропі, Азії і на Близькому Сході, спільно з Всесвітньою організацією інтелектуальної власності (WIPO). За цим рейтингом, Україна віднесена до європейських країн з доходом вище середнього. У 2019 р. Україна дещо погіршила свої позиції, опинившись на 47 сходинці та втративши чотири позиції. У 2020 р. очікуваним місцем за цим індексом для України є 40.

ICT Development Index (IDI) [20] - індекс розвитку IKT, запропонований $\mathrm{OOH}$, який розраховується спеціальним підрозділом ООН Міжнародним союзом електрозв'язку (ITU) - це організація, що визначає стандарти в галузі телекомунікацій та радіо. Індекс характеризує рівень розвитку інформаційно-комунікаційних технологій. Публікується щорічно з 2009 р., є агрегованим показником, який поєднує 11 індикаторів. Він використовується для моніторингу та порівняння розвитку інформаційних та комунікаційних технологій. Індекс дає змогу оцінити 
рівень і еволюцію розвитку ІКТ; прогрес у розвитку ІКТ як у розвинених, так і в країнах, що розвиваються; цифровий розрив, тобто відмінності між країнами з погляду рівня розвитку IКТ; а також потенціал розвитку IКТ та те, наскільки країни можуть використовувати технології для сприяння економічному зростанню в контексті наявних можливостей та навичок. Індекс $є$ глобальним і відображає зміни, що відбуваються в країнах з різними рівнями розвитку ІКТ. Як випливає 3 рис. 2, офіційна публікація індексу за 2018 та 2019 рр. відсутня. У 2018 р. індекс не публікувався, оскільки декілька країн висловили занепокоєння щодо достовірності показника. Після перевірки даних, отриманих від країн у 2019 р., проведено два семінари щодо надання країнами конкретної інформації. Офіційно прийнято рішення, що з 2019 р. індекс розраховуватиметься на основі переглянутого набору показників. Той факт, що існує ряд країн, які висловили занепокоєння щодо публікації індексу через його недостовірність, вимагає проведення консультацій з усіма державами-членами. Після їх завершення, що планується навесні 2020 р., індекс буде офіційно опубліковано. Рейтинг України за цим показником у 2020 р. заплановано на рівні 50 місця.

Global Competitiveness Index (GCI) [23] - глобальний індекс конкурентоспроможності, що розраховується за методологією Всесвітнього економічного форуму $(W E F)$. Показник визначається на основі оцінки діяльності установ, ефективності інфраструктури, рівня сприйняття IКТ, макроекономічної стабільності, інноваційності бізнесу тощо. Україна прагне досягти у 2020 р. 60 позиції у рейтингу Global Competitiveness Index (GCI).

Таким чином, вивчення особливостей оцінки розвитку цифровізації, розуміння місця України у світових рейтингах надає можливість шукати шляхи ефективного підвищення ії позицій, а також умови для розвитку цифрової економічної інфраструктури, побудови дієвої та сучасної цифрової економіки.

Системний підхід, багатогранність та комплексність тем курсу "Цифрова економіка України" роблять його прикладним, універсальним, актуальним та цікавим для вивчення. Ще з часів Конфуція та Сократа наставники завжди усвідомлювали дуальність мети освіти: осягнути минуле й одночасно підготувати молодь до викликів майбутнього. Ця аксіома як ніколи актуальна й тепер - у часи безпрецедентно швидких змін: від професій, яких ще не існує, до рішення проблем, яких зараз не можна уявити, і до використання технологій, яких ще не винайшли.

Висновки. Формуючи соціальні, фахові та цифрові компетентності, когнітивні й емоційні навички, саме освіта спроможна надати і бізнесу, і громадянам гнучкість, інтелект, креативність, закласти основу для реалізації. Використання цифрових платформ надає можливість для кожного українця стати генератором власного ВВП як частини ВВП України, досягнути успіху в часи соціальних і економічних змін. У ході дослідження обгрунтовано необхідність формування цифрових 
компетентностей (Digital skills) майбутніх фахівців різних сфер економіки України, органів влади та громадськості у контексті розвитку глобального тренду цифрової трансформації суспільства. Розроблено методологічний алгоритм побудови курсу "Цифрова економіка України" для здобувачів вищої освіти України.

Результати досліджень, представлені у статті, будуть корисними науковцям, науково-педагогічним працівникам, здобувачам вищої освіти та практикам, які займаються проблематикою цифровізації суспільства, формуванням цифрових компетентностей, і у подальшому можуть бути використані при розробленні курсів, присвячених аспектам цифрових трансформацій, застосуванню сучасних цифрових технологій в управлінні економічними системами.

\section{СПИСОК ВИКОРИСТАНИХ ДЖЕРЕЛ}

1. Звіт про охоплення цифровізації. Digital Spillover Measuring the true impact of the digital economy. URL: https:// www.oxfordeconomics.com/recent-releases/ digital-spillover (дата звернення: 07.04.2020).

2. Digital BCG. The Digital FutureIsNow. URL: https://www.bcg.com/digitalbcg/overview.aspx (дата звернення: 07.04.2020).

3. Digital Transformation Initiative. URL: http://reports.weforum.org/digitaltransformation (дата звернення: 07.04.2020).

4. Аполов О. Г., Зыков О. А., Аполова О. О. От "цифровизации" к "цифровой экономике". Экономика и предпринимательство. 2018. № 4. С. 73-77.

5. Бухт Р., Хикс Р. Определение, концепция и измерение цифровой экономики. Вестник международныхх организаций. 2018. Т. 13. № 2. С. 143-172.

6. Джусов О. А., Альпаков С. С. Цифрова економіка: структурні зрушення на міжнародному ринку капіталу. Міжнародні відносини. 2016. № 9. Серія "Економічні науки".

7. Гудзь О. Є. Цифрова економіка: зміна цінностей та орієнтирів управління підприємствами. Економіка. Менеджмент. Бізнес. 2018. № 2 (24).

8. Карчева Г. Т., Огородня Д. В., Опенько В. А. Цифрова економіка та їі вплив на розвиток національної та міжнародної економіки. Фінансовий простір. 2017. № 3. T. 27. C.13-21.

9. Коляденко С. В. Цифрова економіка: передумови та етапи становлення в Україні і у світі. Економіка. Фінанси. Менеджмент: актуальні питання науки і практики. 2016. № 6. С. 105-112.

10. Писаренко Т. В., Кваша Т. К. та ін. Стан інноваційної діяльності та діяльності у сфері трансферу технологій в Україні у 2017 році: аналітична довідка. Київ: УкрIНTЕI, 2018. 98 с.

11. Піжук О. І. Сучасні методологічні підходи до оцінювання рівня цифрової трансформації економіки. БізнесІнформ. 2019. № 7. C. 39-47. URL: https://doi.org/10.32983/2222-4459-2019-7-39-47.

12. Липов В. Непреднамеренные последствия, гармония, комплементарность и экономические системы: "визуализация" "невидимой руки". Економіка розвитку. 2010. № 1. С. 80-83. 
13. Одотюк I. В. Національна інноваційна система України: структура, недоліки інноваційної спеціалізації і шляхи їх усунення. Ефективна економіка. 2019. № 11. URL: http://www.economy.nayka.com.ua/?op=1\&z=7375 (дата звернення: 07.04.2020). DOI: 10.32702/2307-2105-2019.11.3.

14. Ляшенко В. І., Вишневський О.С.Цифрова модернізація економіки України як можливість проривного розвитку: монографія; НАН України, Ін-т економіки пром-сті. Київ, 2018. 252 с.

15. Future Work Skills 2020. URL: https://uqpn.uq.edu.au/files/203/LIBBY\% 20MARSHALL\%20future_work_skills_2020_full_research_report_final_1.pdf.

16. Східне Партнерство - Концентруючись на ключових пріоритетах та конкретних досягненнях. URL: http://eap-csf.org.ua/wpcontent/uploads/2017/02/PDF1_Ukr.pdf.

17. Europass - інструмент для оцінювання цифрової компетентності. URL: https://ec.europa.eu/jrc/en/digcomp/digital-competence-framework.

18. $95 \%$ крупних компаний не отвечают требованиям нового цифрового бизнеса: исследование ESG по заказу Dell EMC. URL: https:// https://www.dell.com/ learn/ua/ru/uacorp1/press-releases/2017-04-25-esg-study-it-transformationmaturity-curve.

19. Новікова Н. Л., Науменко Р. А., Ільїна А. О. Маркери професійної компетентності державних службовців в контексті нової моделі публічного управління. Економіка Украӥни. 2018. № 9 (682). С. 85-98.

20. International Telecommunications Union ICT Development Index 2016-2017. URL: https://www.itu.int/net4/ITU-D/idi/2017/index.html.

21. Tapscott D. The Digital Economy: Promise and Perilin the Age of Networked Intelligence. McGraw-Hill, 342, 1995.

22. The Global Innovation Index 2018. URL: https://www.globalinnovationindex.org/ gii-2018-report.

23. The Global Competitiveness Report 2017-2018. URL: http://www3.weforum.org/ docs/GCR20172018/05FullReport/TheGlobalCompetitivenessReport2017-2018.pdf.

24. The Networked Readiness Index. URL: http://reports.weforum.org/ globalinformation-technology-report-2016/networked-readiness-index/?doing wp_cron $=1558349353.7612900733947753906250$.

Стаття надійшла до редакиії 08.04.2020.

Mazaraki A., Novikova N., Sonko Yu. Digital determinants of training specialists' trends.

Background. The new era of digitalization, which has rapidly entered the world, results of the fourth industrial revolution (Industry 4.0) make radical adjustments to the traditional way of life, dramatically transforming society. Relocation of analog operations to the Internet, development of digital environment, replacement of classic management models and business processes with digital, produce a new format of industrial production, open up new opportunities for personalization of offers for each client.

The aim of the research is the substantiation of necessity of digital skills formation of future specialists in different spheres of Ukraine's economy, authorities and public in the context of development of the global trend of digital transformation of society and development of methodological algorithms for the organization of the course "Digital Economy of Ukraine" for the students of Ukraine.

Materials and methods. The materials of the researches were quantitative indicators of development of the process of society digitalization, data of international ratings of Ukraine, publiccations of scientists, official reports of international organizations, normative legal acts and so forth. 
Results. The objective of the course "Digital Economy of Ukraine" is to provide the university graduates of various specialties the basic knowledge necessary for managing economic objects. Analyzing recent researches and publications, five key conditions can be identified for successful digitization in Ukraine: accessibility and perception, competitive advantage, overall responsibility, relevance and commitment, and also security.

The basic principles of implementation of these conditions are reliability, practicality and comprehensiveness. Special attention is paid to the digital transformation of the agrarian sphere of Ukraine as a new stage of its development in this course. The issues of digital transformation in the health care of Ukraine is a separate theme of the course. It will be interesting for the students to become familiar with the trends of digital trade transformation, taking into account the specificity of KNUTE. The theme of assessment of digitization processes development is equally important and interesting for the students.

Conclusion. The necessity of digital competencies formation (Digital skills) of the global trend development of the society digital transformation is substantiated in the research. A methodological algorithm for the course organization "Digital Economy of Ukraine" for the students of Ukraine has been developed. According to the developers of the course "Digital Economy of Ukraine", the systematic approach, versatility and complexity of the topics make it applicable, versatile, relevant and interesting to study.

Keywords: digital economy, digital skills, digital trends, educational process, quality of education, digitization.

\section{REFERENCES}

1. Digital Spillover Measuring the trueimpact of the digital economy. www.oxfordeconomics.com. Retrieved from https:// www.oxfordeconomics.com/recentreleases/digital-spillover [in English].

2. Digital BCG. The Digital Future Is Now. www.bcg.com. Retrieved from: https://www.bcg.com/digital-bcg/overview.aspx (referred dat: 07.04.2020) [in English].

3. Digital Transformation Initiative. Retrieved from http://reports.weforum.org/digitaltransformation (referred dat: 07.04.2020) [in English].

4. Apolov, O. H., Zykov, O. A., \& Apolova, O. O. (2018). Ot "tsyfrovyzatsyy" k "tsyfrovoiekonomyke" [From digitalisation to digitaleconomy]. Ekonomyka y predprynymatelstvo - Economics and entrepreneurship, 4, 73-77 [in Russian].

5. Bukh, R., \& Heeks, R. (2018). Defining, Conceptualisingand Measuring the Digital Economy. Vestnik mezhdunarodnyh organizacij - International Organizations Research Journa. (Vol. 13), 2, 143-172 [in Russian].

6. Dzhusov, O. A., \& Alpakov, S. S. (2016). Tsyfrova ekonomika: strukturni zrushennia na mizhnarodnomu rynku kapitalu [The digital economy: structural shifts in the inter national capital market]. Mizhnarodni vidnosyny - International Relations, 9 [in Ukrainian].

7. Hudz, O. (2018). Tsyfrova ekonomika: zmina tsinnostei ta oriientyriv upravlinnia pidpryiemstvam [The Digital Economy: Changing the Valuesand Landmarks of Enterprise Management]. Ekonomika .Menedzhment. Biznes - Economy. Management. Business, 2 (24) [in Ukrainian].

8. Karcheva, H. T. (2017). Tsyfrova ekonomika ta yii vplyv na rozvytok natsionalnoi ta mizhnarodnoi ekonomiky [The edigital economy and its impacton the development of national and international economies]. Finansovyi prostir - Financial space, 3, 13-21 [in Ukrainian].

9. Koliadenko, S. V. (2016). Tsyfrova ekonomika: peredumovy ta etapy stanovlennia v Ukraini i u sviti [The Digital Economy: Prerequisites and Stages of Formationin Ukraine and in the World]. Ekonomika. Finansy. Menedzhment: aktualni pytannia nauky i praktyky - Economy. Finances. Management: topical issues of science and practice, 6, 105-112 [in Ukrainian]. 
10. Pysarenko, T. V., \& Kvasha, T. K. (2018). Stan innovatsiinoi diialnosti ta diialnosti u sferi transferu tekhnolohii v Ukraini u 2017 rotsi: analitychna dovidka [State of Innovation and Technology Transfer Activityin Ukrainein 2017: Analytical Reference]. Kyiv: UkrINTEI [in Ukrainian].

11. Pizhuk O. I. (2019). Suchasni metodolohichni mpidkhody do otsiniuvannia rivnia tsyfrovoi transformatsii ekonomiky [Modern methodological approaches to assessing the level of digitaltrans formation of the economy]. BiznesInform, 7, 39-47. Retrieved from https://doi.org/10.32983/2222-4459-2019-7-39-47 [in Ukrainian].

12. Lipov, V. (2010). Neprednamerennye posledstviya, garmoniya, komplementarnosti ekonomicheskie sistemy: "vizualizatsiya" "nevidimoyruki" [Unpremeditated Consequences, Harmony, Complementarity and Economic Systems: "Visualization" of "Invisible Hand"]. Ekonomika rozvytku - Economics of development, 1, 80-83 [in Russian].

13. Odotyuk, I. (2019). Natsionalna innovatsiina systema Ukrainy: struktura, nedoliky innovatsiinoi spetsializatsiii shliakhy yikhusunennia [National innovation system of Ukraine: structure, deficiencies of innovatives pecialization and ways of theire limination]. Efektyvna ekonomika - Efective economy, 11. Retrieved from http://www.economy.nayka.com.ua/?op=1\&z=7375 (referred dat: 07.04.2020). DOI: 10.32702/2307-2105-2019.11.3 [in Ukrainian].

14. Liashenko, V. I., \& Vyshnevskyi, O. S. (2018). Tsyfrova modernizatsiia ekonomiky Ukrainy yak mozhlyvist proryvnoho rozvytku [Digital Modernization of the Ukrainian Economyas a Breakthrough Opportunity]; NAN Ukrainy, In-t ekonomiky prom-sti. Kyiv [in Ukrainian].

15. 15.Future Work Skills (2020). Retrieved from https://uqpn.uq.edu.au/files/203/ LIBBY\%20MARSHALL\%20future_work_skills_2020_full_research_report_final_1.pdf [in English].

16. Skhidne Partnerstvo - Kontsentruiuchys na kliuchovykh priorytetakh ta konkretnykh dosiahnenniakh [Eastern Partnership - Focusing on keypriorities and concreteachi evements]. Retrieved from http://eapcsf.org.ua/wpcontent/uploads/2017/02/PDF1_Ukr.pdf [in Ukrainian].

17. Europass - instrument dlia otsiniuvanni atsyfrovoik ompetentnosti [Europassis a tool for assessing digital competence]. Retrieved from https:/ec.europa.eu/jrc/en/digcomp/digitalcompetence-framework [in Ukrainian].

18. 95\% krupnykh kompanyi ne otvechaiut trebovanyiam novoho tsyfrovoho byznesa yssledovanye ESG pozakazu Dell EMC [95\% of large companies do not meet the requirements of a new digital business. - ESG research commissioned by Dell EMC]. Retrieved from https:// https://www.dell.com/learn/ua/ru/uacorp1/press-releases/201704-25-esg-study-it-transformation-maturity-curve [in Russian].

19. Novikova, N. L., Naumenko, R. A., \& Il'i'na, A. O. (2018). Markery profesiinoi kompetentnosti derzhavnykh sluzhbovtsiv $\mathrm{v}$ konteksti novoi modeli publichnohou pravlinnia [Markers of professional competence of civilservants in the context of the newmodel of public administration]. Ekonomika Ukrainy - Economy of Ukraine, 9 (682), 85-98 [in Ukrainian].

20. International Telecommunications Union ICT Development Index 2016-2017. Retrieved from https://www.itu.int/net4/ITU-D/idi/2017/index.html_in English].

21. Tapscott, D. (1995). The Digital Economy: Promise and Perilin the Age of Networked Intelligence. McGraw-Hill, 342 [in English].

22. The Global Innovation Index (2018). Retrieved from https://www.globalinnovationindex.org/ gii-2018-report[in English].

23. The Global Competitiveness Report 2017-2018. www3.weforum.org. Retrieved from http://www3.weforum.org/docs/GCR20172018/05FullReport/TheGlobalCompetitivene ssReport2017-2018.pdf [in English].

24. The Networked Readiness Index. reports.weforum.org. Retrieved from http://reports.weforum.org/globalinformation-technology-report-2016/networked-readinessindex/?doing_wp_cron=1558349353.76129007339477539062509 [in English]. 